\title{
Economic Contribution of Wildlife to Bushmeat Market in Ikire, Osun State, Nigeria
}

\author{
"ADEBOWALE, TK; ODUNTAN, OO; ADEGBENJO, AE; AKINBODE, AS \\ Department of Forestry and Wildlife Management, Federal University of Agriculture, Abeokuta, Ogun State, Nigeria \\ *Corresponding Author Email: adebowaletk@funaab.edu.ng; Tel: +2348030420767
}

\begin{abstract}
This paper assessed the economic contribution of wildlife to bushmeat market in Ikire, Osun State, Nigeria. Primary data were collected using semi-structured questionnaire and in-depth interview of targeted respondents. Bush meat sellers in Irewole local government area, Ikire were sampled. Data were analyzed using descriptive statistics, budgetary analysis and likert scale analysis. The result showed that majority of the bushmeat sellers were females $(55.9 \%)$ with a mean age of 41 years. Most of the bushmeat sellers strongly agreed (4.91 \pm 0.09$)$ that they generate more income from bushmeat trade, $4.71 \pm 0.17$ equally noted that customers prefer to purchase bushmeat than convectional meat type while $1.56 \pm 0.19$ disagreed that seasonal change affects customer's preferences for bushmeat in the markets. Also, $5.00 \pm 0.0,4.82 \pm 0.13,4.74 \pm 0.17$ respectively believes that bushmeat are more delicious, better source of protein, more of medicinal value when compared with conventional meat type. Furthermore, an average of $3.70 \pm 0.2$ had cultural sentiments for the consumption of bush meat. An average net profit per respondent yielded $\mathrm{N3}, 565.53$, while BCR and profitability index are 1.95 and 0.95 respectively. Conclusively, bushmeat trading is a profitable and very lucrative enterprise.
\end{abstract}

DOI: https://dx.doi.org/10.4314/jasem.v25i4.14

Copyright: Copyright (C) 2021 Adebowale et al. This is an open access article distributed under the Creative Commons Attribution License (CCL), which permits unrestricted use, distribution, and reproduction in any medium, provided the original work is properly cited.

Dates: Received: 14 February 2021; Revised: 26 March 2021; Accepted: 12 April 2021

Keywords: Wildlife, livelihoods, income, food security and utilization

Wildlife and forests are extremely important to poor rural households, particularly in tropical forest regions, for a number of products and services, including food, food security, income, livelihoods and fuel-wood (FAO, 2009; Fa et al., 2015; MilnerGulland et al., 2013), and many have proposed that rural populations depend or rely on wildlife products, or that the forest is necessary to them. Wild ungulates and other animals are generally acknowledged as valuable sources of meat and other commodities in many tropical societies, and are widely consumed in many West African countries, as they contribute between an estimated $20 \%$ and $100 \%$ of the animal protein consumed (Jayeoba et al., 2013).

Most wildlife animals consumed by the populace are locally termed "Bushmeat" and are consumed by both rural and urban dwellers with variation in magnitude of its exploitation and consumption (Bifarin et al., 2008). Bush meat constitute of vast array of species ranging from cutter, snakes, duikers, bush pig, snail, guinea fowl, hare, brush tailed porcupine, giant rat, edible frogs etc. (Abulude, 2007). Bushmeat contributes significantly to household income and food security in many locations across Sub-Saharan Africa (Lindsey et al., 2013; Nielsen et al., 2017; Ahmadi et al., 2018). Soaga et al., (2014) estimated the value of bushmeat consumed in Southern Nigeria at N20 million while the total value for the entire country was put at N30 million per annum. Today the value of animal protein from wild animals and fresh water fish consumed annually is well over N200 million (Olaoye, 2010) yet FAO, (2006) categorized Nigeria is a protein- deficient country. Akinyemi and Oduntan (2004) stressed that people collect, purchase and eat bush meat for their animal protein supply either because they have no other source or cannot afford alternative sources.

Bushmeat utilization constitutes a significant source of revenue (Milner-Gulland et al., 2003), particularly where the trade is driven by increased bushmeat consumption in urban areas. In West and Central Africa, where bushmeat is mostly sold in open markets (Cowlishaw et al., 2005) the value of bushmeat and income earned from bushmeat trade can more easily be quantified (Kümpel et al., 2010). This paper assessed contributions of wildlife to bushmeat economy in an urban area of a developing country and the perception of respondents on bushmeat sales and consumption.

\section{MATERIALS AND METHODS}

Study Area: The study was carried out in Ikire, Irewole Local Government Area of Osun State. Irewole Local Government with its headquarters in Ikire was created in 1976 following the Local Government Reform of that year. In 1989 and 1996 the present Ayedade Local 
Government and Isokan Local Government areas respectively were carved out of the old Irewole area. With this development the present Irewole Local Government is made of people of Ikire who share common ancestry. Local Government Area in the South and Ayedire local Government in the North. Irewole Local Government shares common boundaries with Ayedaade Local Government Area in the East, Ife-North Local Government area in the South East, Egbeda Local Government Area of Oyo State in the West, Isokan Irewole Local Government is situated in the South Western part of Osun State with altitudes of between 121.92 meters and 298.704 meters above the sea level.

Data Collection: Primary data were collected using semi-structured questionnaire and in-depth interview of targeted respondents. A snowballing technique was used in selecting the respondents. A total of 45 respondents were interviewed for this study.

Respondents cut across hunters (14) representing 31\%, ethno-medicine sellers (22) representing 49\% and bushmeat sellers (9) representing 20\%. Questionnaire information include the demographic data such as age, sex, marital status and income, perception of the respondents and the contribution of wildlife to bushmeat economy in the study area. Furthermore, personal contacts, oral interviews and observations were used during visitation; this aided the primary data collection techniques.

Data Analysis: Socio-economic characteristics of respondents and the species of bushmeat were subjected to descriptive statistic. Budgetary techniques were used in analyzing the costs and returns structure of bushmeat sellers in the study area. Likert scale analysis was adopted to evaluate respondents' perception towards the sales of bushmeat in the study area.

Gross Margin $(G M)$ : The gross margin was calculated using

$$
\text { Gross Margin }(\mathrm{GM})=\mathrm{TR}-\mathrm{TVC}
$$

Where: $\mathrm{TR}=$ Total Revenue TVC $=$ Total Variable Cost

Net Income (NI): The net income was calculated using the formula:

$$
\begin{gathered}
\mathrm{NI}=\mathrm{GM}-\mathrm{TFC} \\
\mathrm{TFC}=\mathrm{TC}-\mathrm{TVC}
\end{gathered}
$$

Where: $\mathrm{GM}=$ Gross Margin; $\mathrm{TVC}=$ Total Variable Cost from scale of the operation; TFC $=$ Total Fixed Cost of the operation; TC $=$ Total Cost of scale of the operation; NI = Net Income

Rate of Returns on Investment (RORI): The rate of returns on investment was calculated in determining the rate of return to capital invested in the business according to the respective scale of operation in determining the profitability of investment using mathematical formula below:

$$
\frac{N I}{T C} \times 100
$$

Where: $\mathrm{NI}=$ Net income; $\mathrm{TC}=$ Total Cost

\section{RESULTS AND DISCUSSION}

Socio-economic Characteristics of Respondents: The result from Table 1 reveals that majority (55.9\%) of the respondents involved in the sales of bush meat were female. This trend is in agreement with Oduntan et al., (2018) that reported $58 \%$ of the bush meat sellers are females. Also, majority (61.8\%) of the respondents involved in the sales of bush meat had secondary education with a monthly income of 20,001 - $\$ 40,000$ in the study area.

Cost and Return Analysis of Bushmeat Sales in the Study Area: Table 2 shows the results of cost and return analysis. The result revealed that an average respondent sold a quantity of two bushmeat ( $\$ 3$, 500.00), generating an average of $\$ 7308.82$ as revenue per month.

The total fixed cost were incurred from purchase of fixed items such as mesh wire/net, drum, table etc. which represents $43.33 \%$ while variable items such as firewood, seasoning and kerosene represents $56.67 \%$ with a total cost of production of $\$ 3,743.29$ per month.

An average bushmeat sellers generated gross profit of $\$ 5,187.64$ and a net profit of $¥ 3,565.53$ per month with the benefit-cost ratio estimated at 1.95 and Rate of Return on Investment (RORI), 0.95. Thus, implies that bushmeat sales is a very profitable business.

Perception of Respondents on Bushmeat Sales and Consumption: The result in table 3 presents the distribution of perception of respondents on bushmeat. The result showed that majority $(97.1 \%)$ of respondents strongly agreed that they generate more income from the sales of bushmeat in the market. This is an indication that the respondents perceived that the return from the investment is high. 
Also, majority (91.2\%) of the respondents strongly agreed that customers prefer to buy bushmeat than convectional meat type while $(67.6 \%)$ disagreed that seasonal change affects customer's preferences for bushmeat. Furthermore, all (100\%) of the respondents strongly agreed that bushmeat are more delicious compared to other convectional meat type while
(91.2\%) of consumers strongly agreed that bushmeat are of more medicinal value to man. About (67.6\%) of the respondents disagreed that bushmeat have cultural/spiritual implications. The result further reveals that $(94.2 \%)$ of the respondents strongly affirmed that bushmeat are of better source of protein than other convectional meat type.

Table 1: Socio-economic Characteristics of Respondents

\begin{tabular}{llll}
\hline Variables & Frequency & Percentage (\%) & Mean \\
\hline Age (years) & 6 & & \\
$25-30$ & 6 & 17.6 & 41.32 years \\
$31-35$ & 3 & 8.9 & \\
$36-40$ & 9 & 26.5 & \\
$41-45$ & 9 & 26.5 & \\
Above 45 & 7 & 20.5 & \\
Total & 34 & 100.0 & \\
Sex & & & \\
Male & 15 & 44.1 & \\
Female & 19 & 55.9 & \\
Total & 34 & 100.0 & \\
Marital status & & & \\
Single & 4 & 11.8 & \\
Married & 30 & 88.2 & \\
Total & 34 & 100.0 & \\
Educational status & & & \\
None & 4 & 11.8 & \\
Primary education & 9 & 26.5 & \\
Secondary education & 21 & 61.8 & \\
Total & 34 & 100.0 & \\
Years of experience & & & \\
1-10 & 15 & 44.1 & \\
11-20 & 15 & 44.1 & \\
21-30 & 4 & 11.8 & \\
Total & 34 & 100.0 & \\
Income (N monthly) & & & \\
1-20,000 & 2 & 5.9 & \\
20,001-40,000 & 19 & 55.9 & \\
40,001-60,000 & 11 & 32.3 & \\
Above 60,000 & 2 & 5.9 & \\
Total & 34 & 100.0 & \\
\hline
\end{tabular}

Table 2: Cost and Return Analysis of Bushmeat Sales in the Study Area

\begin{tabular}{lll}
\hline Variable & Value $\mathbf{( N )}$ & Percentage (\%) \\
\hline Total revenue & $7,308.82$ & \\
$\begin{array}{l}\text { Average selling price } \\
\text { Average quantity (2.09) }\end{array}$ & $3,500.00$ & \\
$\begin{array}{l}\text { Depreciated Fixed cost } \\
\text { Rent on shop/space }\end{array}$ & & \\
Mesh wire/net & 113.11 & 3.02 \\
Drum & 271.01 & 7.24 \\
Knife & 441.18 & 11.79 \\
Covering net & 113.73 & 3.04 \\
Table & 208.82 & 5.58 \\
Total fixed cost & 474.26 & 12.67 \\
Variable cost & $1,622.11$ & 43.33 \\
Firewood & & \\
Kerosene & $1,194.12$ & 31.90 \\
Seasoning & 680.88 & 18.19 \\
Total Variable Cost (TVC) & 246.18 & 6.58 \\
Total cost (TFC+TVC) & $2,121.18$ & 56.67 \\
Gross margin (TR-TVC) & $3,743.29$ & 100.00 \\
Net income (GM-TFC) & $5,187.64$ & \\
RORI & $3,565.53$ & \\
BCR & 0.95 & \\
Profitability Index GP/ GR & 1.95 & \\
\hline
\end{tabular}


Table 3: Perception of Respondents on Bushmeat Sales and Consumption

\begin{tabular}{|c|c|c|c|c|c|c|c|c|}
\hline $\mathbf{S} / \mathbf{N}$ & Perceptional statements & $\begin{array}{l}\text { SA (\%) } \\
(5)\end{array}$ & $\begin{array}{c}\text { A (\%) } \\
\text { (4) }\end{array}$ & $\begin{array}{c}\mathrm{U}(\%) \\
\text { (3) }\end{array}$ & $\begin{array}{c}(\%) \\
\text { (2) }\end{array}$ & $\begin{array}{l}\text { SD (\%) } \\
\text { (1) }\end{array}$ & Mean & $\begin{array}{l}\text { Mean } \\
\text { error }\end{array}$ \\
\hline 1 & $\begin{array}{l}\text { I make more income from the } \\
\text { sales of bushmeat in the } \\
\text { market }\end{array}$ & $33(97.1)$ & - & - & $1(2.9)$ & - & 4.91 & \pm 0.09 \\
\hline 2 & $\begin{array}{l}\text { My customers prefer to buy } \\
\text { bushmeat than convectional } \\
\text { meat type }\end{array}$ & 31 (91.2) & - & $1(2.9)$ & - & $2(5.9)$ & 4.71 & \pm 0.17 \\
\hline 3 & $\begin{array}{l}\text { Seasonal change affects } \\
\text { customer's preferences for } \\
\text { bushmeat }\end{array}$ & $2(5.9)$ & $1(2.9)$ & - & $8(23.6)$ & $23(67.6)$ & 1.56 & \pm 0.19 \\
\hline 4 & $\begin{array}{l}\text { Bushmeat are more delicious } \\
\text { compared to other } \\
\text { convectional meat type }\end{array}$ & $34(100.0)$ & - & - & - & - & 5.00 & \pm 0.00 \\
\hline 5 & $\begin{array}{l}\text { Bushmeat are of more } \\
\text { medicinal value to man }\end{array}$ & $31(91.2)$ & $1(2.9)$ & - & - & $2(5.9)$ & 4.74 & \pm 0.17 \\
\hline 6 & $\begin{array}{l}\text { Bushmeat have } \\
\text { cultural/spiritual implications }\end{array}$ & $1(2.9)$ & $1(2.9)$ & - & $9(26.6)$ & $23(67.6)$ & 1.47 & \pm 0.15 \\
\hline 7 & $\begin{array}{l}\text { Bushmeat are of better source } \\
\text { of protein than other } \\
\text { convectional meat type }\end{array}$ & $32(94.2)$ & - & $1(2.9)$ & - & $1(2.9)$ & 4.82 & \pm 0.13 \\
\hline
\end{tabular}

Conclusion: The majority of the bushmeat sellers are still in their productive age, although female are more involved in the sales than men. Education and training are found to be a significant factor that promotes the business as the respondents had secondary education. The costs and return analysis showed that sale of bushmeat is a profitable venture. In addition, the sellers described it as more nutritious, delicious, better protein source, and customer's preference. Domestication of several species of mammals should be encouraged to improve bush meat availability.

Acknowledgements: I wish to express my profound gratitude to God Almighty for the grace he accorded me on this research work. My gratitude also goes to my supervisor Dr. Oduntan O.O, department of Forestry and Wildlife Management, federal University of Agriculture Abeokuta for his valuable support and assistant during the research work.

\section{REFRENCES}

Abulude, FO (2007). Determination of the chemical composition of bush meats found in Nigeria. Am. J. Food Techno. 2(3), 153-160.

Ahmadi, S; Maman, S; Zoumenou, R; Massougbodji, A; Cot, M; Glorennec, P; Bodeau-Livinec, F. (2018). Hunting, Sale, and Consumption of Bushmeat Killed by Lead-Based Ammunition in Benin. Int J. Environ. Res. and Pub. Health. 15, 1140 .

Akinyemi, AF; Oduntan OO (2004). An evaluation of the effect of conservation legislation on wildlife offences in Yankari National Park, Bauchi state, Nigeria. Nig. J. Forestry. 34(1): 28 - 35.
Bifarin, JO; Ajibola, VA.J; Fadiyimu, AA (2008). Analysis of marketing of bushmeat in Idanre Local Government area of Ondo State, Nigeria. Afr. J. of Agric. Res. 3(10): 667-671.

Cowlishaw, G; Mendelson; Rowcliffe, JM (2005). Evidence for post-depletion sustainability in a mature bushmeat market. J. Appl. Eco. 42: 460468.

FAO (2006). Year book of Fishery Statistics Summary Tables. www.fao.org/fi/statist.asp

FAO, (2009). "The major significance of 'minor' forest products: the local use and value of forests in the West African humid forest zone." FAO Community Forestry Note (No. 6)

Fa, JE; Olivero, J; Real R; Farfán, MA; Marquez, AL; Brown, D; Margetts, B; Nasi, R; (2015). Disentangling the relative effects of bushmeat availability on human nutrition in central Africa. Sci. Reports. 5: 8168.

Jayeoba, WA; Okonkwo, MC; Omonona, AO; Oladele, ON; Suleman, RA; Ojo, OS; Olumuyiwa, SA (2013). Implication and consequences of bushmeat trade on Wildlife population In. Forest industry in a dynamic global environment (eds. Labode P., Idumah, F.O, Ogunsanwo, O.Y and Azeez, I. O). Proceeding of 35 th annual conference of Forestry Association of Nigeria (FAN), 11th- 16th February, 2013, Sokoto.

Kümpel, NF (2006). Incentives for sustainable hunting of bushmeat in Río Muni, Equatorial Guinea. 
Institute of Zoology. University of London, London.

Lindsey, PA; Balme, G; Becker, M; Begg, C; Bento, C; Bocchino, C; Zisadza-Gandiwa, P (2013). The bushmeat trade in African savannas: Impacts, drivers, and possible solutions.Bio. Conserve. 160, 80-96.

Milner-Gulland, EJ; Bennett, EL (2003). Wild meat: the bigger picture. Trends Eco. Evol. 18(7), 351357.

Nielsen, MR; Pouliot, M; Meilby, H; Smith-Hall, C; Angelsen, A (2017). Global patterns and determinants of the economic importance of bushmeat. Bio. Conserv. 215, 277-287.
Oduntan, OO; Ojo, VA; Mbaya ,YP; Akinyemi, AF; Adebowale, TK; Joe-Martins, O (2018). Economic Contributions and Sellers Perception of Wildlife to Bushmeat Market in Abeokuta, Ogun State, Nigeria. J. Forest. Sci. Environ, 3 (1): 43 47

Olaoye, OJ (2010). Dynamics of the Adoption Process of Improved Fisheries Technologies in Lagos and Ogun States Nigeria. A Ph.D. Thesis in the Department of Aquaculture and Fisheries Management, University of Agriculture Abeokuta, Ogun State, Nigeria. 337.

Soaga, J. A., Shotuyo, A. L. A., Oduntan, O. O; Fatoki, J. G. (2014). Economic analysis of bushmeat trade in Abeokuta, Ogun State. J. Agric. Sci. Environ. 14, 97-108. 